\title{
Characterisation of preparation layers in nine Danish Golden Age canvas paintings by SEM-EDX, FTIR and GC-MS
}

\author{
C. K. Andersen ${ }^{1 *}$, I. Bonaduce ${ }^{2}$, A. Andreotti ${ }^{2}$, J. van Lanschot ${ }^{1}$ and A. Vila ${ }^{3}$
}

\begin{abstract}
This study explores the materials used in the preparation layers of nine paintings from the Danish Golden Age as a first approach to understanding the variation in use of materials in the nineteenth century as well as the potential for their degradation. Paintings on canvas have traditionally been suspected to be particularly sensitive to high moisture levels because of the changing quality of materials in the nineteenth century. The explanations have partly included the mechanisation of production methods and partly a more experimental approach to painting. Additionally, collagen-based glue sizing of the canvas is suspected to respond dimensionally to changes in relative humidity. In this study, pigments, fillers and binding media in the preparation layers of nine paintings by different artists were identified using scanning electron microscopy with energy dispersive X-ray spectroscopy, Fourier transform infrared spectroscopy and gas chromatography-mass spectrometry. The study shows a relatively low degree of variation in materials used in grounds. Surprisingly, no collagen-based binder was found in any of the nine paintings, suggesting that the canvases were not glue sized. All paintings contained calcium, lead, a drying oil and egg, even though only few contemporary recipes in painter's manuals included egg as an ingredient for preparation layers. These results suggest that the commercial producers of prepared canvas may not have followed the manuals that were written for painters. Egg may have been added in order to increase flexibility and durability of ready primed canvases that were stored and sold in rolls. Moreover, the egg-oil emulsion has the advantage of being more viscous than a pure oil paint and could thus be used without sizing the canvas, rendering the primed canvas less stiff and less responsive to changes in relative humidity. The advantages of using egg in the ground are obvious, and this use, as well as the lack of glue size, has implications for the long-term preservation of the paintings in changing environmental conditions. These results imply that these particular paintings might be less sensitive to relative humidity changes than expected due to the lack of hygroscopic glue.
\end{abstract}

Keywords: Danish Golden Age paintings, Nineteenth century, Preparation layers, Egg-oil emulsion ground, Gas chromatography-mass spectrometry (GC-MS), Fourier transform infrared spectroscopy (FTIR), Energy dispersive X-ray spectroscopy (SEM-EDX), Moisture sensitivity

\section{Introduction}

Danish Golden Age paintings were painted in the first half of the nineteenth century and are highly esteemed as an invaluable part of Danish cultural heritage. The painters involved in this study are Christoffer Wilhelm

\footnotetext{
*Correspondence: cka@kadk.dk

${ }^{1}$ The Royal Danish Academy of Fine Arts, Schools of Architecture, Design and Conservation, Esplanaden 34, 1263 Copenhagen K, Denmark Full list of author information is available at the end of the article
}

Eckersberg (1783-1853), also called 'the father of Danish painting, and some of his most famous pupils at the Royal Danish Academy of Fine Arts: Christen Schillerup Købke (1810-1848), Wilhelm Bendz (1804-1832) and Carl Christian Constantin Hansen (1804-1880), as well as Johan Thomas Lundbye (1818-1848), who was the pupil of professor J.L. Lund, Eckersberg's colleague at the academy.

This study concentrates on how the canvases used by these painters were prepared before paint application. The 
purpose of the preparation layers was to produce a uniform background for the painters to work on. In some cases, the procedure for preparing a canvas included sizing, which was the application of a layer of glue from bones, mammal skin, fish swim bladders, or flour paste to the raw canvas [1]. On top of this glue layer, one or more ground layers containing pigment, fillers, and binding media would then be applied. In some cases, a brownish or reddish layer with more inexpensive materials such as ochre or chalk that was bound in oil or suspended in an emulsion was used to fill the voids of the canvas. A thinner layer of more expensive materials was then added to supply the desired background colour. In some cases, painters probably applied their own ground(s) on top of a commercially primed canvas $[2,3]$.

The colour and texture of the ground layer could influence the tonality and surface appearance of the finished painting; in addition, the materials chosen for the preparation layers can affect the way a painting age. In Denmark as well as abroad, canvas paintings of the nineteenth century have been suspected to be extra sensitive to humidity and water, which cause shrinkage and cracking [4-6]. Theories regarding variations of preparation layers can be investigated through studies of historic recipes and mockups but, to understand the full potential of the preparation layers for influencing degradation, the historic painting materials must be characterised through analyses.

Colour and preparation layers have been studied for some painters from the Danish Golden Age [4, 7] as well as the previous generation. Thus, we know that there was a shift in the use of colours of grounds (from coloured to white) in Denmark from Nicolai Abildgaard [8] through Jens Juel [9] to Christoffer W. Eckersberg [7]. Previous studies furthermore suggest that painters primarily painted on Danish-produced canvases due to the high customs duties on canvases during the first half of the nineteenth century [5]. This behaviour suggests that canvases were locally produced and prepared except for a few specific instances. Eckersberg's journals show that he bought ready-primed canvases or employed a local craftsman to prepare his canvases [4, 7].

For a canvas that was prepared for commercial sale, we may assume that there were practical issues to consider such as their rolling, storing and shipping [10]. These issues means that flexibility would be an issue of importance, and the binding media plays a significant role in defining these qualities. Certain materials such as collagen-based glues would increase both stiffness and hygroscopic behaviour if used in the preparation of the canvases and might cause failure in the added paint layer $[11,12]$, whereas we would expect oils to provide more flexibility and less reactivity to moisture.

Recipes suggest that the binding media in grounds in the first half of the nineteenth century were mainly oil or glue or a mixture of both, but a variety of other materials was also introduced. The use of starch is well known [2, 13] and, used less frequently, casein, egg and natural rubber [14]. Grounds were required to have a certain absorbency, which was achieved with glue or an emulsion of oil and water as a binder [15]. However, as mentioned, a certain flexibility that would allow the primed canvases to be rolled for storage or shipping would have become increasingly important with the commercialisation of prepared canvases. It must have been a difficult balance to strike, as more oil provided more flexibility but less absorbency.

This study explores the materials (organic and inorganic components) used in the preparation layers of nine Danish Golden Age paintings in order to improve our understanding of the manufacturing processes and to achieve an impression of the degree of variation in the ground and size layers used at the time. It is furthermore a first approach to understanding the potential for physical degradation by mechanisms such as mechanical stress and to understand the possible sensitivity to changes in relative humidity in order to improve the decisionmaking platform for conservation and storage of the paintings.

\section{Experimental methods \\ Golden age painting samples}

Statens Museum for Kunst (the National Gallery of Denmark, SMK) possesses a number of samples from the tacking edges of paintings, which include the most prominent Danish Golden Age artworks. These samples were removed by conservators in the first half of the 1960s before conservation treatment, which was usually the application of a wax resin lining. This removal was done in order to have material for later research, and the samples are rather large by modern standards. The size varies from $2 \times 50 \mathrm{~mm}$ to $20 \times 240 \mathrm{~mm}$.

Samples from paintings by influential artists have been chosen for this study (Table 1) and represent different trends and periods of the Danish Golden Age. The paintings furthermore represent different genres (portraits, landscapes and seascapes); two of the nine paintings were executed outside Denmark, namely, in Paris (no. 3) and Rome (no. 4). These canvases were therefore likely to have been prepared abroad.

The following techniques were used for the analytical investigation of the materials in ground samples:

\section{Scanning electron microscopy with energy dispersive X-ray spectroscopy (SEM-EDX)}

SEM-EDX was performed on cross sections taken from the pieces of tacking edge that were removed during conservation in the 1960s (see Table 1). Samples were 


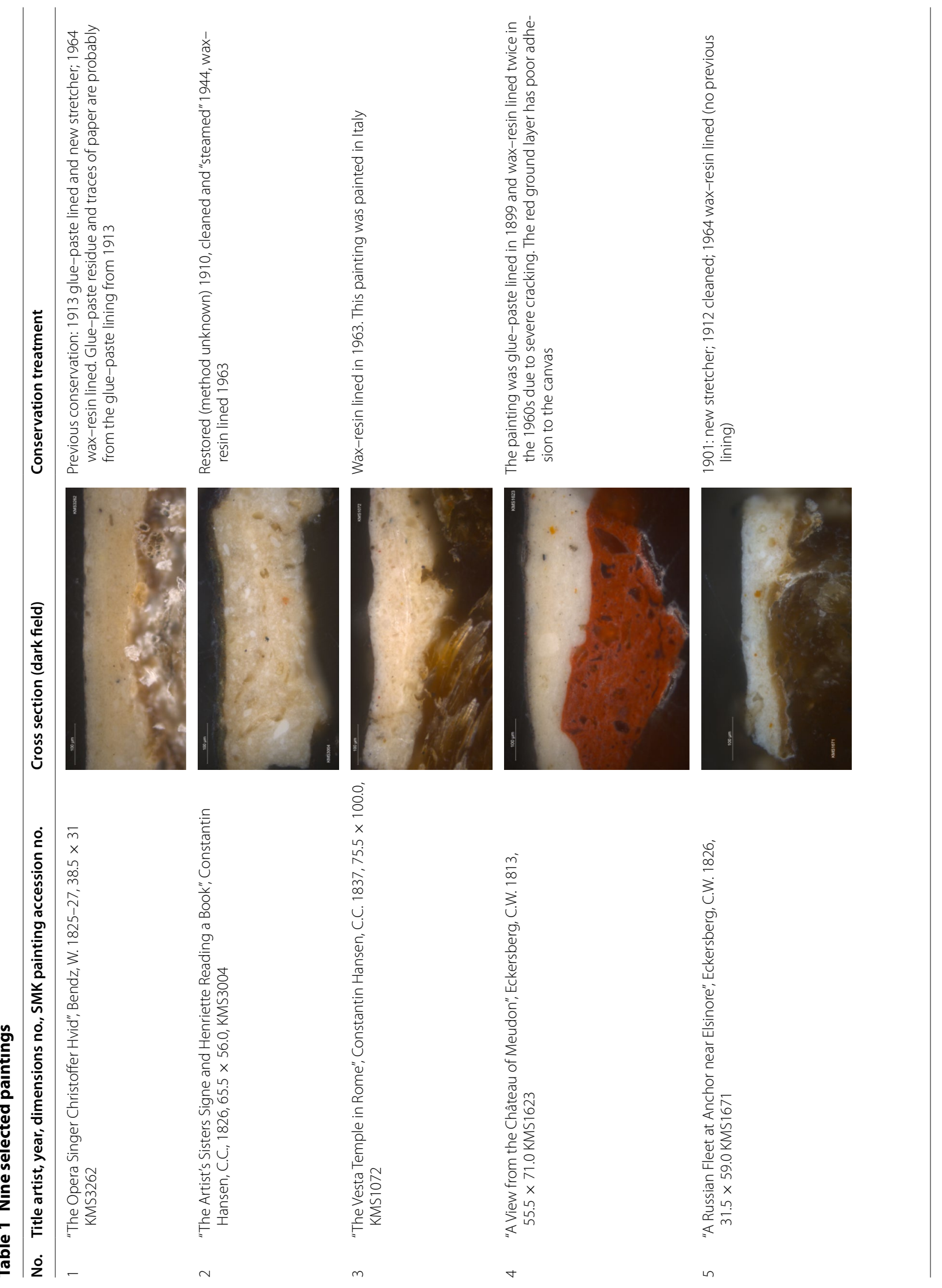




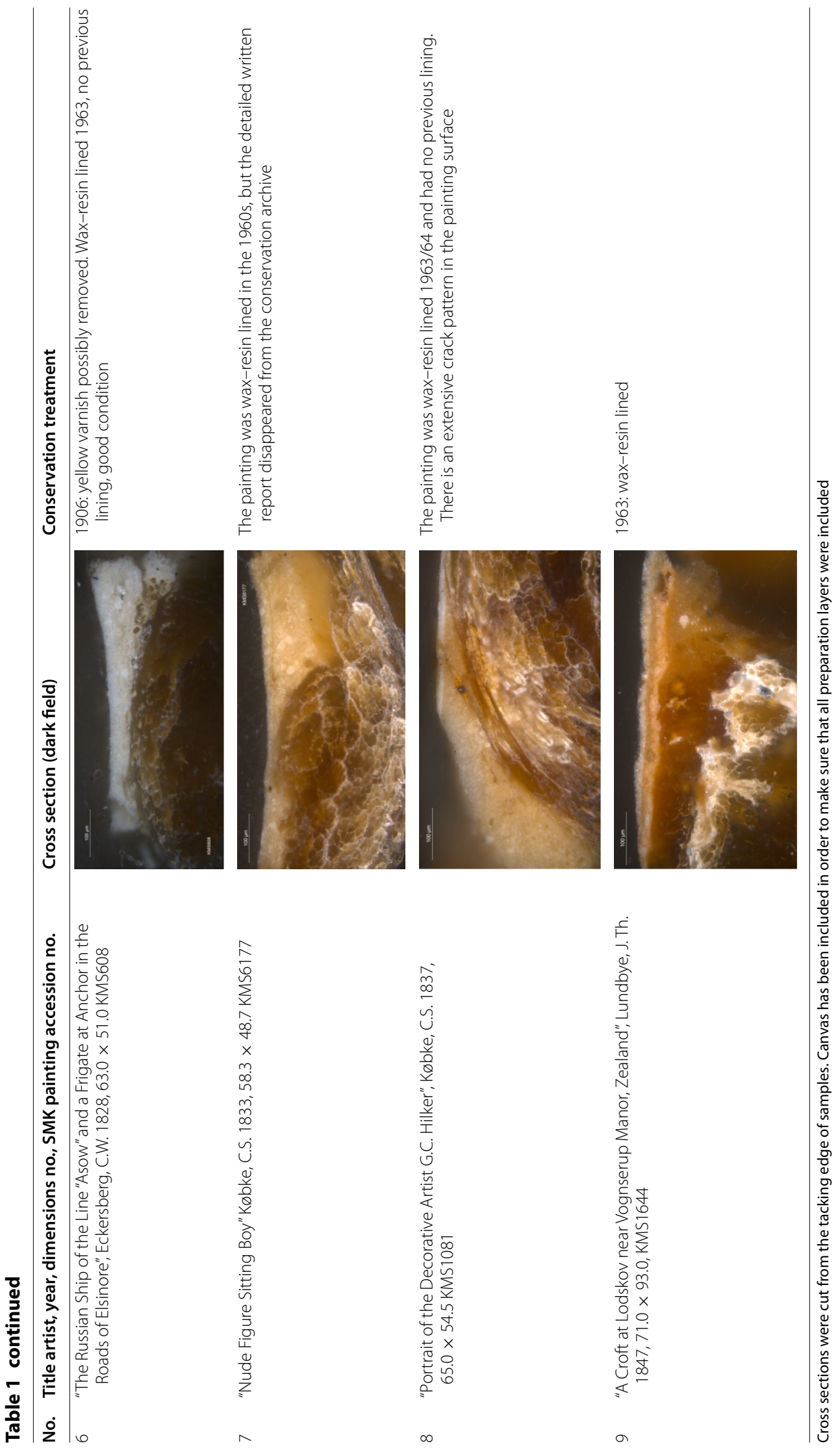


embedded in Serifix resin from Struers (methyl ethyl ketone peroxide, butanone and dimethyl phthalate), and the cross sections were polished with sandpaper. Cross sections were analysed in order to obtain elemental information using a Hitachi S-3400N equipped with a Bruker detection system. Spectra and elemental maps were recorded using $20-\mathrm{kV}$ voltage, $50-\mu \mathrm{A}$ probe current and 10 -mm working distance.

\section{Fourier transform infrared spectroscopy (FTIR)}

A sample of the ground (approximately $0.5 \times 0.5 \mathrm{~mm}$ ) was taken with a scalpel. The sample was positioned in a Perkin Elmer Spectrum 100 Fourier transform infrared (FTIR) apparatus equipped with an attenuated total reflectance (ATR) diamond/ZnSe crystal. The side that had been closest to the canvas was in direct contact with the ATR crystal. Spectra were acquired in the range from $4000-650 \mathrm{~cm}^{-1}$ with a spectral resolution of $4 \mathrm{~cm}^{-1}$ and at a pressure of $100 \mathrm{~N}$ for 4 scans. To corroborate SEMEDX results from the different layers, cross sections of sample numbers 4 and 9 (KMS1623 and KMS1644) were also measured by micro fourier transform interferometer ( $\mu$ FTIR). In these two specific cases, FTIR analyses were performed with a Bruker Tensor $24^{\circledR}$ spectrometer coupled to a Hyperion ${ }^{\circledR} 3000$ microscope that was equipped with a focal plane array (FPA) detector. Measurements were performed in ATR mode with a $20 \times$ germanium crystal objective with a refractive index of 4.01 that has an anvil design in an 80- $\mu \mathrm{m}$ tip. An average of 32 scans was used in an accumulation range of $900-3600 \mathrm{~cm}^{-1}$ and at a spectral resolution of $4 \mathrm{~cm}^{-1}$.

\section{Gas chromatography-mass spectrometry (GC-MS)}

Samples (between 0.2 and $1.0 \mathrm{mg}$ in weight) were analysed with an analytical procedure based on a wet chemical pretreatment of the sample that includes extraction, desalting and hydrolysis steps. This procedure was done in order to separate the same microsamples into three fractions so that they could be separately analysed by GC-MS. The three fractions were: a saccharide fraction (solution of persilylated dithioacetal derivatives of aldoses and uronic acids that were derived from the hydrolysis of saccharide materials), an amino acid fraction (solution of tert-butyldimethylsilyl derivatives of amino acids that were derived from the hydrolysis of proteins) and a resinous lipid fraction (solution of trimethylsilyl derivatives of acids, alcohols and neutral compounds that were derived from the hydrolysis of lipids, resins and waxes). The procedure is described in detail in the literature [16].

A $6890 \mathrm{~N}$ GC system gas chromatograph coupled with a 5973 mass selective detector single-quadrupole mass spectrometer equipped with a split-splitless injector and a $6890 \mathrm{~N}$ GC system gas chromatograph (Agilent
Technologies, Palo Alto, CA) coupled with a 5975 mass selective detector single-quadrupole mass spectrometer equipped with PTV injector, also by Agilent Technologies, were used. The MS transfer line temperature was $280{ }^{\circ} \mathrm{C}$; the MS ion source temperature was kept at $230{ }^{\circ} \mathrm{C}$, and the MS quadrupole temperature was at $150{ }^{\circ} \mathrm{C}$. For the gas chromatographic separation, an HP$5 \mathrm{MS}$ fused silica capillary column (5\% diphenyl/95\% dimethyl-polysiloxane, $30 \mathrm{~m} \times 0.25 \mu \mathrm{m}$ i.d., $0.25 \mu \mathrm{m}$ film thickness, Agilent Technologies) with a deactivated silica precolumn $(2 \mathrm{~m} \times 0.32 \mu \mathrm{m}$ i.d. $)$ was used. The carrier gas was used in the constant flow mode (He, purity 99.995\%) at $1.2 \mathrm{~mL} \mathrm{~min}{ }^{-1}$. The mass spectrometer was operated in the positive EI mode $(70 \mathrm{eV})$, and MS spectra were recorded both in total ion current (TIC) and single ion monitoring (SIM) modes.

\section{Results}

SEM-EDX and FTIR-ATR data are summarised in Tables 2 and 3, and GC-MS data relative to the three analysed fractions are reported in Tables 4, 5 and 6.

For the characterisation of the source of the proteinaceous material, the amino acid profile of each sample whose protein content was above the quantitation limit of the procedure was subjected to a multivariate statistical analysis that included a data set of 121 reference samples of animal glue, casein, and egg (whole egg, albumen and yolk) [17] using principal component analysis (PCA). The resulting score plot is presented in Fig. 1.

PCA score plot relative to the ground samples with a protein content above the QL, using a database of reference samples of animal glue, casein and egg.

\begin{tabular}{|c|c|c|}
\hline No. & SMK accession no. & Elements \\
\hline 1 & KMS3262 & Pb, Ca (Al) \\
\hline 2 & KMS3004 & $\mathrm{Ca}, \mathrm{Pb}(\mathrm{Si}, \mathrm{Al}, \mathrm{Fe}, \mathrm{Na})$ \\
\hline 3 & KMS1072 & $\mathrm{Pb}, \mathrm{Ca}(\mathrm{Mg})$ \\
\hline 4 & KMS1623 & $\begin{array}{l}\text { Whitish layer: } \mathrm{Pb}(\mathrm{Ca}, \mathrm{Al}, \mathrm{Si}, \mathrm{Fe}, \mathrm{K}) \\
\text { Red layer: } \mathrm{Si}, \mathrm{Fe}, \mathrm{Al}(\mathrm{Ca}, \mathrm{K}, \mathrm{Pb} / \mathrm{S})\end{array}$ \\
\hline 5 & KMS1671 & Pb, Ca (Al) \\
\hline 6 & KMS608 & $\mathrm{Pb}, \mathrm{Ca}(\mathrm{Al})$ \\
\hline 7 & KMS6177 & $\mathrm{Ca}, \mathrm{Pb}(\mathrm{Si}, \mathrm{Mg}, \mathrm{Al}, \mathrm{K})$ \\
\hline 8 & KMS1081 & $\begin{array}{l}\text { Whitish upper layer: } \mathrm{Pb}(\mathrm{Ca}) \\
\text { Lower layer: } \mathrm{Ca}(\mathrm{Pb}, \mathrm{Si})\end{array}$ \\
\hline 9 & KMS1644 & $\begin{array}{l}\text { Whitish and yellow upper layer: } \mathrm{Pb}, \mathrm{Ba}, \mathrm{Fe} \\
\quad(\mathrm{Si}, \mathrm{Al}, \mathrm{Na}) \\
\text { Inter layer: particles of } \mathrm{Si}, \mathrm{Al}, \mathrm{Na} \\
\text { Lower layer: } \mathrm{Ca}\end{array}$ \\
\hline
\end{tabular}

Italics elements are present in relatively high levels. Elements in parentheses are present at trace levels. $\mathrm{Pb}$ (lead), Ca (calcium), Al (aluminium), Si (silicon), Fe (iron), $\mathrm{Na}$ (sodium), Mg (magnesium), $\mathrm{K}$ (potassium), S (sulphur), and Ba (barium) 
Table 3 Absorption features in the region between 4000 and $600 \mathrm{~cm}^{-1}$ and their assignments in the FTIR-ATR spectra of the samples collected from the ground samples

\begin{tabular}{|c|c|c|c|c|c|c|}
\hline No. & SMK accession no. & Lipids & Proteins & $\begin{array}{l}\text { Calcium sulphate and/ } \\
\text { or other compounds }\end{array}$ & Calcium carbonate & Lead carbonate (basic) \\
\hline 1 & KMS3262 & $\begin{array}{l}2921 \mathrm{~s} \\
2852 \mathrm{~s} \\
1720 \mathrm{sh}\end{array}$ & $\begin{array}{l}1638 s \\
1530 s \\
1327 s h \\
1240 w \\
1208 w \\
1151 \mathrm{w} \\
1078 \mathrm{sh} \\
1030 \mathrm{sh}\end{array}$ & ca. $1100 \mathrm{br}$ & $\begin{array}{l}2515 \mathrm{sh} \\
1795 \mathrm{w} \\
1384 \mathrm{~s} \mathrm{br} \\
875 \mathrm{vs} \\
715 \mathrm{~s}\end{array}$ & $\begin{array}{l}3536 \mathrm{sh} \\
1400 \mathrm{~s} \mathrm{br} \\
1045 \mathrm{~s} \\
756 \mathrm{br} \\
680 \mathrm{~s} \\
838 \mathrm{~s} \text { (neutral) }\end{array}$ \\
\hline 2 & KMS3004 & $\begin{array}{l}2921 m \\
2852 m \\
1708 w\end{array}$ & $\begin{array}{l}1638 \mathrm{~m} \\
1530 \mathrm{vW} \\
1151 \mathrm{w}\end{array}$ & Silicate ca. $1000 \mathrm{~s} \mathrm{br}$ & $\begin{array}{l}2515 \mathrm{sh} \\
1795 \mathrm{w} \\
1391 \mathrm{~s} \mathrm{br} \\
875 \mathrm{vs} \\
715 \mathrm{~s}\end{array}$ & $\begin{array}{l}1400 \mathrm{~s} \mathrm{br} \\
756 \mathrm{br} \\
680 \mathrm{~s}\end{array}$ \\
\hline 3 & KMS1072 & $\begin{array}{l}2921 \mathrm{~s} \\
2852 \mathrm{~s} \\
1738+1715 \mathrm{sh}\end{array}$ & $\begin{array}{l}1638 \mathrm{~s} \\
1530 \mathrm{~s} \\
1327 \mathrm{sh}\end{array}$ & $\begin{array}{l}3530 w \\
3403 w \\
1622 w \\
1110 s b r\end{array}$ & $\begin{array}{l}1393 \mathrm{~s} \mathrm{br} \\
875 \mathrm{vs} \\
715 \mathrm{~s}\end{array}$ & $\begin{array}{l}3536 \mathrm{sh} \\
1400 \mathrm{~s} \mathrm{br} \\
1045 \mathrm{~s} \\
756 \mathrm{br} \\
680 \mathrm{~s}\end{array}$ \\
\hline \multirow[t]{2}{*}{4} & $\begin{array}{l}\text { KMS1623 } \\
\text { Top layer }\end{array}$ & $\begin{array}{l}2921 \mathrm{~s} \\
2852 \mathrm{~s} \\
1730 \mathrm{sh}\end{array}$ & & & & $\begin{array}{l}1400 \mathrm{~s} \mathrm{br} \\
1045 \mathrm{~s} \\
\left(+\mathrm{Pb} \text { carboxylates ca. } 1515 \mathrm{~cm}^{-1}\right)\end{array}$ \\
\hline & $\begin{array}{l}\text { KMS1623 } \\
\text { Bottom layer }\end{array}$ & $\begin{array}{l}2921 \mathrm{~s} \\
2852 \mathrm{~s} \\
1730 \mathrm{sh}\end{array}$ & $\begin{array}{l}1638 \mathrm{br} \\
1537 \mathrm{br}\end{array}$ & Silicate ca. $1000 \mathrm{~s} \mathrm{br}$ & $\begin{array}{l}1393 \text { w br } \\
\text { (carbonate) }\end{array}$ & \\
\hline 5 & KMS1671 & $\begin{array}{l}2921 \mathrm{~s} \\
2852 \mathrm{~s} \\
1720 \mathrm{sh}\end{array}$ & $\begin{array}{l}1638 \mathrm{~s} \\
1530 \mathrm{~s} \\
1327 \mathrm{sh} \\
1240 \mathrm{w} \\
1208 \mathrm{w} \\
1151 \mathrm{w} \\
1078 \mathrm{sh} \\
1030 \mathrm{sh}\end{array}$ & ca. $1100 \mathrm{br}$ & $\begin{array}{l}2515 \mathrm{sh} \\
1795 \mathrm{w} \\
1384 \mathrm{~s} \mathrm{br} \\
875 \mathrm{vs} \\
715 \mathrm{~s}\end{array}$ & $\begin{array}{l}3536 \mathrm{sh} \\
1400 \mathrm{~s} \mathrm{br} \\
1045 \mathrm{~s} \\
756 \mathrm{br} \\
680 \mathrm{~s} \\
838 \mathrm{~s} \text { (neutral) }\end{array}$ \\
\hline 6 & KMS608 & $\begin{array}{l}2921 \mathrm{~s} \\
2852 \mathrm{~s} \\
1710 \mathrm{sh}\end{array}$ & $\begin{array}{l}1638 \mathrm{~s} \\
1530 \mathrm{~s} \\
1151 \mathrm{w} \\
1030 \mathrm{sh}\end{array}$ & $\begin{array}{l}\text { ca. } 1100 \mathrm{~s} \mathrm{br} \\
\text { ca. } 673 \mathrm{w}\end{array}$ & $\begin{array}{l}2515 \mathrm{sh} \\
1795 \mathrm{w} \\
1384 \mathrm{~s} \mathrm{br} \\
875 \mathrm{vs} \\
715 \mathrm{~s}\end{array}$ & $\begin{array}{l}3534 \\
1400 \text { s br } \\
680 \text { s } \\
838 \text { s w (neutral) }\end{array}$ \\
\hline 7 & KMS6177 & $\begin{array}{l}2921 \mathrm{~s} \\
2852 \mathrm{~s} \\
1738 \mathrm{sh} 1715 \mathrm{sh}\end{array}$ & $\begin{array}{l}1638 s \\
1530 s \\
1327 s h \\
1240 w \\
1078 s h \\
1030 \text { sh }\end{array}$ & $\begin{array}{l}3530 w \\
3403 w \\
1110 s b r \\
673 s\end{array}$ & $\begin{array}{l}1393 \mathrm{~s} \mathrm{br} \\
875 \mathrm{vs} \\
715 \mathrm{~s}\end{array}$ & $\begin{array}{l}1400 \mathrm{sbr} \\
680 \mathrm{~s}\end{array}$ \\
\hline 8 & KMS1081 & $\begin{array}{l}2921 \mathrm{~s} \\
2852 \mathrm{~s} \\
1720 \mathrm{~m}\end{array}$ & $\begin{array}{l}1638 \mathrm{~m} \\
1530 \mathrm{~m} \\
1327 \mathrm{sh} \\
1240 \mathrm{w} \\
1208 \mathrm{w} \\
1151 \mathrm{w} \\
1078 \mathrm{sh} \\
1030 \mathrm{sh}\end{array}$ & $\begin{array}{l}1620 \mathrm{br}(w ?) \\
1110 \mathrm{~s}(w ?) \\
673 \mathrm{~s}(w ?)\end{array}$ & $\begin{array}{l}2515 \mathrm{sh} \\
1795 \mathrm{w} \\
1384 \mathrm{~s} \mathrm{br} \\
875 \mathrm{vs} \\
715 \mathrm{~s}\end{array}$ & $\begin{array}{l}3536 \mathrm{sh} \\
1400 \mathrm{~s} \mathrm{br} \\
1045 \mathrm{~s} \\
756 \mathrm{br} \\
680 \mathrm{~s}\end{array}$ \\
\hline
\end{tabular}


Table 3 continued

\begin{tabular}{|c|c|c|c|c|c|c|}
\hline No. & SMK accession no. & Lipids & Proteins & $\begin{array}{l}\text { Calcium sulphate and/ } \\
\text { or other compounds }\end{array}$ & Calcium carbonate & Lead carbonate (basic) \\
\hline 9 & $\begin{array}{l}\text { KMS1644 } \\
\text { Top layer }\end{array}$ & $\begin{array}{l}2921 \mathrm{~s} \\
2852 \mathrm{~s} \\
1730 \mathrm{sh}\end{array}$ & & $\begin{array}{l}\mathrm{BaSO}_{4} \text { with bands ca. } 1170 \\
1112,1075,981 \mathrm{~s}\end{array}$ & & $\begin{array}{l}1400 \mathrm{~s} \mathrm{br} \\
1045 \mathrm{~s} \\
\left(+\mathrm{Pb} \text { carboxylates ca. } 1515 \mathrm{~cm}^{-1} \text { ) }\right.\end{array}$ \\
\hline 10 & $\begin{array}{l}\text { KMS1644 } \\
\text { Bottom layer }\end{array}$ & $\begin{array}{l}2921 \mathrm{~s} \\
2852 \mathrm{~s} \\
1738,1710 \mathrm{sh} \\
1169 \mathrm{w} \\
1094 \mathrm{w}\end{array}$ & & & $\begin{array}{l}2515 \mathrm{sh} \\
1795 \mathrm{w} \\
1389 \mathrm{~s} \mathrm{br} \\
875 \mathrm{vs} \\
715 \mathrm{~s}\end{array}$ & \\
\hline
\end{tabular}

Regarding basic lead carbonate, it is only possible to identify the main components due to the overlap of calcium carbonate, lead carbonate and calcium sulphate peaks. Lead carboxylates could also be present, with bands approximately 1500 and $1400 \mathrm{~cm}^{-1}$; however, because the peaks are located on the same wavelengths as proteinaceous compounds and carbonates, they cannot always be identified

$s$ sharp peak, $m$ medium peak, $w$ weak peak, $b r$ broad band, $v$ very, sh shoulder band

Table 4 Amino acid profile (\%) of samples with a protein content above the detection limit (DL) or quantitation limit (QL)

\begin{tabular}{|c|c|c|c|c|c|c|c|c|c|c|c|c|c|}
\hline No. & SMK accession no. & Ala & Gly & Val & Leu & Ile & Ser & Pro & Phe & Asp & Glu & Hyp & Protein content \\
\hline 1 & KMS3262 & 9.7 & 9.1 & 9.5 & 13.3 & 8.3 & 3.8 & 6.5 & 7.0 & 16.7 & 16.1 & 0.0 & $>Q L$ \\
\hline 2 & KMS3004 & Yes & Yes & Yes & Yes & Yes & Yes & Yes & Yes & Yes & Yes & No & $\begin{array}{l}>\mathrm{DL} \\
<\mathrm{QL}\end{array}$ \\
\hline 3 & KMS1072 & 12.4 & 3.5 & 6.4 & 10.2 & 4.9 & 8.1 & 6.6 & 5.7 & 13.8 & 28.4 & 0.0 & $>Q L$ \\
\hline 4 & KMS1623 & 6.0 & 15.7 & 5.1 & 11.1 & 4.9 & 5.9 & 10.6 & 7.5 & 6.5 & 26.5 & 0.0 & $>Q \mathrm{Q}$ \\
\hline 5 & KMS1671 & 13.8 & 13.9 & 13.0 & 19.2 & 11.9 & 7.2 & 1.8 & 6.1 & 10.4 & 2.7 & 0.0 & $>Q L$ \\
\hline 6 & KMS608 & 4.2 & 2.7 & 5.4 & 8.7 & 5.2 & 37.5 & 1.3 & 1.5 & 13.1 & 20.3 & 0.0 & $>Q \mathrm{~L}$ \\
\hline 7 & KMS6177 & 8.5 & 14.3 & 8.6 & 14.3 & 8.3 & 5.0 & 6.0 & 8.6 & 14.7 & 11.6 & 0.0 & $>Q \mathrm{~L}$ \\
\hline 9 & KMS1644 & Yes & Yes & Yes & Yes & Yes & Yes & Yes & Yes & Yes & Yes & No & $\begin{array}{l}>\mathrm{DL} \\
<\mathrm{QL}\end{array}$ \\
\hline
\end{tabular}

Table 5 Characteristic parameters related to the identification of the source of the glycerolipid material in those samples with a lipid content above the QL

\begin{tabular}{|c|c|c|c|c|c|}
\hline No. & $\begin{array}{l}\text { SMK } \\
\text { accession no. }\end{array}$ & $\begin{array}{l}\text { A/P (azelatic acid/ } \\
\text { palmitic acid) }\end{array}$ & $\begin{array}{l}\text { P/S (palmitic acid/ } \\
\text { stearic acid) }\end{array}$ & $\begin{array}{l}\text { O/S (oleic acid/ } \\
\text { palmitic acid) }\end{array}$ & $\begin{array}{l}\Sigma \text { Dicarboxylic } \\
\text { acids } \%\end{array}$ \\
\hline 1 & KMS3262 & 1.4 & 1.4 & 0.0 & 49 \\
\hline 2 & KMS3004 & 2.6 & 1.3 & 1.3 & 63 \\
\hline 3 & KMS1072 & 1.1 & 3.7 & - & 36 \\
\hline 4 & KMS1623 & 2.6 & 1.3 & 0.1 & 63 \\
\hline 5 & KMS1671 & 1.5 & 1.3 & 0.0 & 51 \\
\hline 6 & KMS608 & 0.9 & 3.0 & 0.4 & 43 \\
\hline 7 & KMS6177 & 1.7 & 0.9 & 0.0 & 51 \\
\hline 8 & KMS1081 & 0.8 & 2.0 & 2.0 & 29 \\
\hline 9 & KMS1644 & 1.5 & 1.3 & 0.0 & 52 \\
\hline
\end{tabular}

The meaning of the reported parameters are discussed in detail in the literature [20]

To determine the source of the saccharide materials, the data were compared to a database of saccharide profiles of reference materials [18], and when polysaccharide gums were hypothesised, they were identified using a decisional scheme that was reported in the literature
[19]. The interpretation of the chromatograms relative to the lipid-resinous fractions was based on the recognition of molecular markers for resins and waxes and quantitative evaluation of mono and dicarboxylic acids for lipids [20]. 


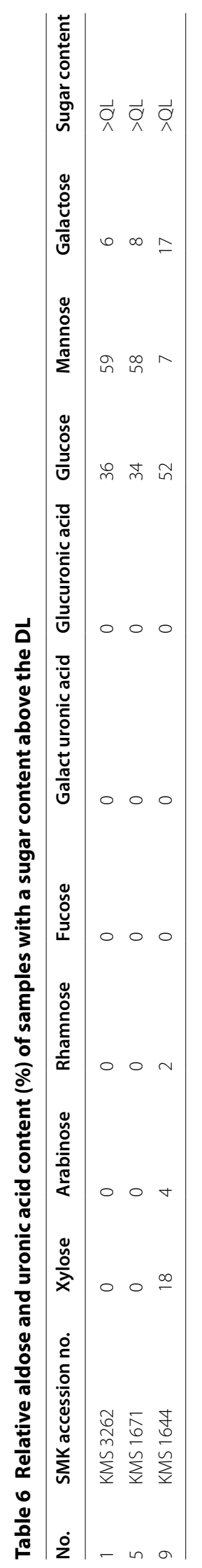




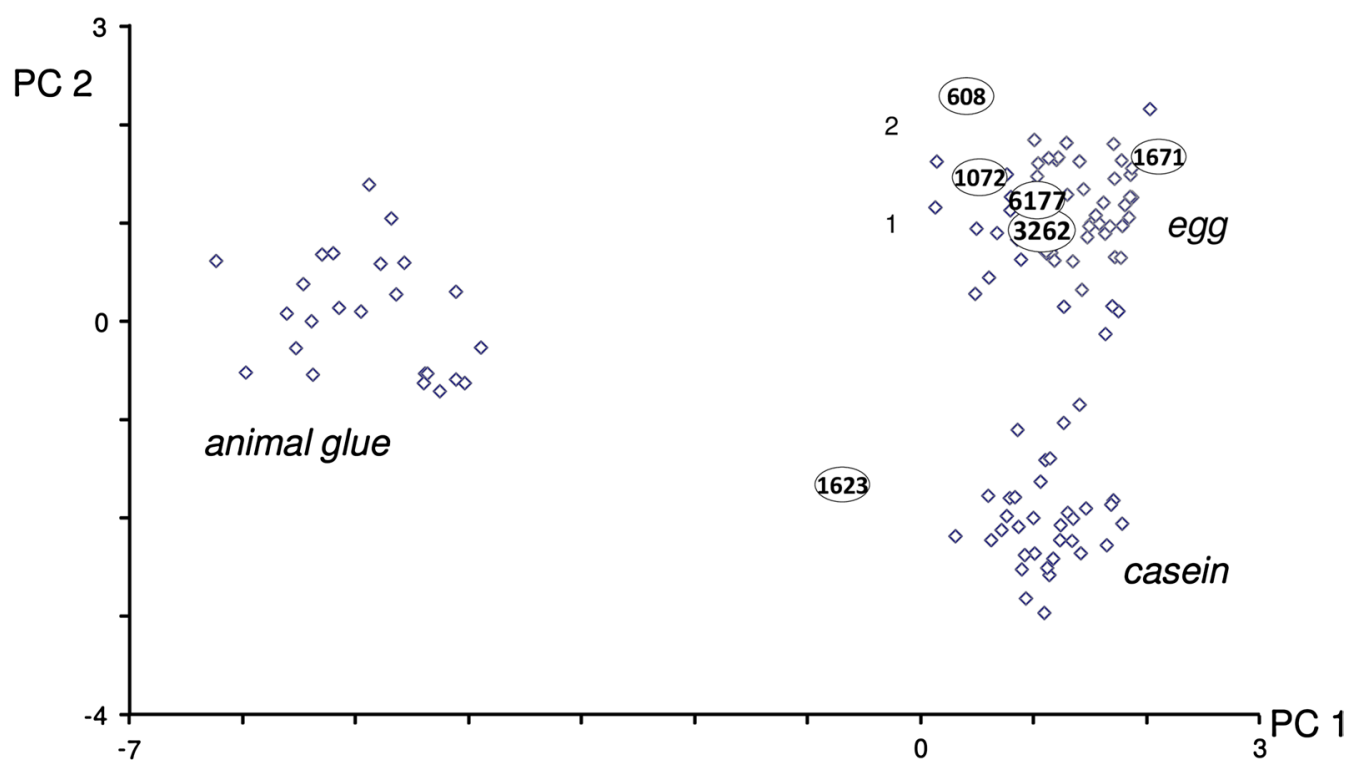

Fig. 1 Principal component analysis (PCA) score plot

Table 7 Overview of suggested content in the nine paintings

\begin{tabular}{|c|c|c|c|c|}
\hline No. & $\begin{array}{l}\text { SMK } \\
\text { accession no. }\end{array}$ & Binders & Pigments and elements & Fillers \\
\hline 1 & KMS3262 & Drying oil (linseed or walnut) + egg & Lead carbonate & $\begin{array}{l}\text { Calcium carbonate, perhaps calcium } \\
\text { sulphate }\end{array}$ \\
\hline 2 & KMS3004 & $\begin{array}{l}\text { Drying oil (perhaps linseed) + egg or } \\
\text { casein }\end{array}$ & Lead carbonate & Silicon and calcium containing filler \\
\hline 3 & KMS1072 & $\begin{array}{l}\text { Drying oil (linseed or walnut) + egg } \\
\quad \text { (whole or yolk) }\end{array}$ & Lead white + (Mg and Si) & Calcium sulphate and calcium carbonate \\
\hline 4 & KMS1623 & Drying oil and egg (whole or yolk) & $\begin{array}{l}\text { Lower layer: iron earth pigment (Fe, Si, } \\
\text { Al, Ca, K and } \mathrm{Pb} / \mathrm{S}) \\
\text { Top layer: lead carbonate + (Ca, Al, Si, } \\
\text { Fe, and } \mathrm{K})\end{array}$ & \\
\hline 5 & KMS1671 & Drying oil + egg (whole or yolk) & Lead carbonate & $\begin{array}{l}\text { Calcium carbonate, perhaps calcium } \\
\text { sulphate }\end{array}$ \\
\hline 6 & KMS608 & Drying oil (linseed or walnut) + egg & $\begin{array}{l}\text { Lead carbonate, perhaps calcium } \\
\text { sulphate }\end{array}$ & $\begin{array}{l}\text { Calcium carbonate, perhaps calcium } \\
\text { sulphate }\end{array}$ \\
\hline 7 & KMS6177 & Drying oil + egg (whole or yolk) & Lead carbonate, calcium sulphate & Calcium carbonate, calcium sulphate \\
\hline 8 & KMS1081 & Drying oil + egg (whole or yolk) & Lead carbonate & Silicon and calcium containing filler \\
\hline 9 & KMS1644 & Drying oil + egg or casein + gum & $\begin{array}{l}\text { Top layer: lead carbonate, Fe, Si, Al, } \\
\mathrm{Na}, \mathrm{Ca} \\
\text { Lower layer: no clear identification }\end{array}$ & $\begin{array}{l}\text { Top layer: barium sulphate } \\
\text { Lower layer: calcium carbonate }\end{array}$ \\
\hline
\end{tabular}

\section{Discussion}

The SEM-EDX data allowed us to obtain the elemental composition and stratigraphic information of the ground layers. The EDX information was complemented by the molecular information on organic and some inorganic compounds that were obtained by FTIR. Analyses done with GC-MS on whole samples allowed us to specifically list the organic compounds that were used in grounds and possible size layers without pointing to the specific layers from which these compounds originate. The data are discussed in the following paragraphs and summarised in Table 7.

Generally, the analysed grounds are rather similar in composition, but minor differences have been noted. The FTIR and SEM-EDX analysis of the examined grounds generally confirmed the presence of lead carbonate and 
calcium carbonate, and in five cases, calcium sulphate was also observed (KMS3262, KMS1072, KMS1671, KMS608, and KMS6177); however, due to the overlap of peaks in the fingerprint area, it is not always possible to confirm its presence. Silicon was observed in five paintings, and silicate was clearly observed by FTIR in two paintings (KMS1623 and KMS3004). Barium sulphate was only found in sample KMS1644. Calcium carbonate, calcium sulphate and barium sulphate were mainly used as fillers in oil grounds, as they become semi-transparent in oil, whereas lead white provided the white colour to the ground. Furthermore, they acted as dryers to catalyse the oxidation of the oil binder. Apart from a slight tinting of some of the white layers in the grounds, a lightbrown bottom layer is the only variation to be found among the pigment composition of the nine grounds [4]. SEM-EDX results from painting number 4 by Eckersberg (KMS1623), which was painted in France, had a red iron earth pigment below the white top layer. The white grounds were also reported in a large survey of Eckersberg paintings [7] and recipes from other European countries [2], confirming a European trend of using white grounds in the period.

GC-MS analyses on the grounds of the nine paintings allowed the identification of a drying oil, most likely linseed or walnut oil, and egg. The oil seemed to have been combined with egg in different amounts in order to form a thick emulsion. It was not possible to determine if yolk or white had been used. The amino acid profiles of egg yolk and egg white proteins are in fact very similar [20], and the P/S ratio could not be used to determine the source of the oil or to verify the presence of the egg lipids. Walnut oil would in fact give rise to similar $\mathrm{P} / \mathrm{S}$ values as a those of a mixture of egg lipids and linseed oil. The $\mathrm{P} / \mathrm{S}$ ratios that were obtained were in fact quite low, and according to the literature, this could be interpreted as being due to linseed oil alone [21]. The absence of egg lipids cannot be verified, as egg might be present in relatively minor amounts and consequently not modifying the fatty acid profile of the drying oil. Moreover, it has been demonstrated that fatty acids escape a paint film in time, and considering that palmitic acid evaporates four times quicker than stearic acid [22], the $\mathrm{P} / \mathrm{S}$ value is expected to significantly decrease over time [23]. The presence of lead white in the preparation layer should make the $\mathrm{P} / \mathrm{S}$ parameters somewhat more reliable, as lead carboxylates are not volatile. In these samples though, saponification, if it occurred, was not complete, as the $v_{\mathrm{as}} \mathrm{COO}^{-}$bands of the glycerolipid materials were still very well visible in the spectra, and the $v_{\text {as }} \mathrm{COO}^{-}$bands of the lead carboxylates, if present, were not distinguishable from the amide II band. The sugar profiles that were observed were in perfect agreement with the presence of egg [18].
Collagen-based compounds, such as animal glue, contain the amino acid hydroxyproline, and the absence of this amino acid in all nine samples ruled out the presence of collagen-based glues in the samples.

Animal glue size was thus not identified in any of the nine samples, although the samples were obtained with great care so that all layers from the canvas on up would be included. Interestingly, this result concurs with discoveries by Stools-Witlox, who concludes that a large proportion of nineteenth century recipes for canvas preparation do not mention a size layer [1].

Furthermore, the analyses evidenced the presence of egg in all cases, a binder that is rarely mentioned in contemporary European sources [1, 2]. However, new materials such as egg did start to occur in recipes in the nineteenth century due to the general trend of experimentation and innovation [1, 24]. As discussed above, the analyses do not clearly show which part of the egg was used because of the simultaneous presence of the drying oil. However, it is well known that egg yolk mixes well with oil due to its emulsifying powers [25, 26].

Conservation-based sources provide an impression of the practical implications of the use of egg-oil grounds. Paints with egg yolk are considered to be strong and durable and have a low tendency to turn yellow, compared to pure oil paints [26, 27]. While egg white is supposed to make brittle paints, yolk-based paints are considered more flexible and tough [28, 29]. A paint based on emulsion of egg and oil would have a higher viscosity than a pure oil ground, and, depending on the particular mixture and the openness of the canvas weave, it could be used directly on a canvas without the use of glue size to prevent it from sinking into the canvas structure.

With an egg-oil ground and no animal glue size, a merchant or artist would probably have been able to roll and store the canvas with ground with a smaller risk of cracks than would have been the case with a glue- or starch-based ground [25]. Furthermore, due to the lack of collagen-based glue, the preparation layer would be less dimensionally responsive at different relative humidity levels, and the risk of mechanical damage could be expected to be lower with this type of preparation. In painting KMS1644, a polysaccharide gum was found. The xylose/arabinose ratio was higher than one, and fucose was absent. Therefore, we can exclude the presence of tragacanth gum and suggest the presence of fruit tree or gum arabic [19], which could very well serve the similar purpose of providing flexibility; alternatively, it could have been used as a sizing agent for the canvas.

KMS3262 and KMS1671 seem quite similar in material composition in the analyses that have been used here, and the two paintings were also painted more or less at the same time but by two different artists. A thread count 
conducted on these two canvas samples suggest that they are slightly different (KMS3262: $10.0 \times 14.5$ threads per centimeter and KMS1671: $15.2 \times 14.5$ threads per centimeter (or $12 \times 14.7$ when measured with automated thread count on the entire painting [7]), although both are tightly woven [4]. Whether the canvases are in fact different remains uncertain, but the results support the hypothesis that painters used the same supplier(s) of ground, and these suppliers may have had a premixed batch of ground that was applied to more canvases.

\section{Conclusions}

SEM-EDX, FTIR and GC-MS analyses of pigments, fillers and binders that were used in grounds of a group of Danish nineteenth century paintings seemed to indicate that the painters of the Danish Golden Age used similar materials. In all the paintings that were analysed, indications of egg-oil mixtures were found as well as lead white and calcium. The latest painting, from 1847, is a little different, as it also contains a gum and barium sulphate. This similarity indicates that certain recipes were favoured amongst the suppliers in Denmark for a period of time or amongst students of the same professor. Furthermore, the results question whether other contemporary countries used similar recipes, since two of these paintings were painted abroad. As animal skin glue seems to be absent in all cases, the findings indicate that these paintings have a relatively low response to relative humidity fluctuations. The presence of egg and gum may indicate a concern for practical matters such as rolling, stretching and storing preprepared canvases.

As all the paintings in this study were wax-resin lined in the 1960s, it does not seem possible to make more general conclusions by comparing the findings reported here and the current condition of the paintings.

\section{Abbreviations}

GC-MS: gas chromatography-mass spectrometry; QL: quantification limit; DL: detection limit; PCA: principal component analysis; PTV: programmed temperature vaporising; El: electron impact; FTIR-ATR: Fourier transform infrared spectroscopy; S: sharp peak; m: medium size peak; w: weak peak; br: broad band; $v$ : very; sh: shoulder band; SEM-EDX: energy dispersive X-ray spectroscopy.

\section{Authors' contributions}

CKA developed the concept of this work. AA, JVL, CKA and AV contributed to acquisition and analysis of the data. AA, IB, AV and JVL contributed to data interpretation. CKA provided context and all authors helped drafting/revising the manuscript. All authors read and approved the final manuscript.

\section{Authors' information}

CKA is an assistant professor and a paintings conservator. Her research focuses on mechanical properties of paintings as well as technical examination of paintings technique. $I B$ is an associate professor in analytical chemistry specialising in analysis of organic materials in cultural heritage objects using gas mass spectrometric-based techniques. AA is a graduated technician specialising in analysis of organic materials in cultural heritage objects using gas mass spectrometric-based techniques. JvL is a conservator with extensive experience in Scanning Electron Microscope analyses. AV is a senior researcher in conservation science who is specialised in analyses of artists' materials using spectroscopic analyses.

\section{Author details}

1 The Royal Danish Academy of Fine Arts, Schools of Architecture, Design and Conservation, Esplanaden 34, 1263 Copenhagen K, Denmark. ${ }^{2}$ Department of Chemistry and Industrial Chemistry, University of Pisa, via Moruzzi 13, 56126 Pisa, Italy. ${ }^{3}$ Centre of Art Technological Studies and Conservation, Sølvgade 48-50, 1307 Copenhagen K, Denmark.

\section{Acknowledgements}

The Conservation Department at Statens Museum for Kunst (SMK) generously provided the paint samples for this study, which was carried out as a collaboration between the Centre for Art Technological Studies and Conservation (CATS) and the University of Pisa. CATS is a strategic research venture between SMK, the National Museum of Denmark and The Royal Danish Academy of Fine Arts, School of Conservation, in Copenhagen.

\section{Competing interests}

The authors declare that they have no competing interests.

Availability of data and materials

Measurements and spectra are shared on ResearchGate.

Funding

The Danish Council for Independent Research, Humanities (FKK).

\section{Publisher's Note}

Springer Nature remains neutral with regard to jurisdictional claims in published maps and institutional affiliations.

Received: 5 March 2017 Accepted: 5 July 2017

Published online: 16 August 2017

\section{References}

1. Stols-Witlox M. Historical recipes for preparatory layers for oil paintings in manuals, manuscripts and handbooks in North West Europe, 1550-1900: analysis and reconstructions [Ph.D]. University of Amsterdam. 2014. http://dare.uva.nl/search?metis.record.id=430263.

2. Witlox M, Carlyle L. A perfect ground is the very soul of the art: ground recipes for oil painting 1600-1900. In: Verger I, editor. ICOM committee for conservation 14th triennial meeting, the Haque, 12-16 September 2005 the Hague. London: James \& James/Earthscan; 2005. p. 519-28.

3. Kirby J, Roy A. Paul Delaroche: a case study of academic painting. In: Wallert A, Hermens E, Peek M, editors. Historical painting techniques, materials, and studio practice: preprints of a symposium, University of Leiden, the Netherlands, 26-29 June 1995; Los Angeles, California. Marina del Rey: The Getty Conservation Institute; 1995. p. 166-75.

4. Andersen CK. Lined canvas paintings. Mechanical properties and structural response to fluctuating relative humidity, exemplified by the collection of Danish Golden Age paintings at Statens Museum for Kunst (SMK) [Ph.D]. Unpublished: KADK Royal Danish Academy of Fine Arts, Schools for Architecture, Design and Conservation, School of Conservation; 2013.

5. Andersen CK, Filtenborg T, Scharff A, Scharff M. The industrialisation of canvas production in Denmark and its implications for the preservation of Danish nineteenth century paintings. In: Ryhl-Svendsen M, Borchersen $\mathrm{K}$, Odder W, editors. Incredible industry — preserving the evidence of industrial society; May 25-27; Copenhagen. Copenhagen: NKF-dk; 2009. p. 39-49.

6. Hedley $\mathrm{G}$. The practicalities of the interaction of moisture with oil paintings on canvas. In: Hedley G, Villers C, editors. Measured opinions: collected papers on the conservation of paintings. London: United Kingdom Institute for Conservation; 1993. p. 112-22.

7. Filtenborg T, Andersen CK. Canvas supports and grounds in paintings by C.W. Eckersberg. In: Townsend JH, Vandivere A, editors. Technology 
\& practice: studying the European visual arts 1800-1850-paintings, sculpture, interiors and art on paper; National Museum of Denmark, Copenhagen, 2016: Archetype; 2017. p. 43-54.

8. Filtenborg T, Vila Espuna A. Between formula and freestyle, Nicolai Abildgaard and 18th-century painting technique. London: Archetype Publications; 2014.

9. Slotsgaard TL. An investigation of the painting technique in portraits by Jens Juel. In: Evans H, Muir K, editors. Studying 18th-century paintings and works of art on paper; CATS Proceedings, II, 2014; Copenhagen: Archetype Publication and CATS (Centre for Art Technological Studies and Conservation; 2015. p. 46-57.

10. Zucker J. From the ground up: the ground in 19th-century American pictures. J Am Inst Conserv. 1999;38(1):3-20.

11. Mecklenburg MF. Some aspects of the mechanical behavior of fabric supported paintings. Washington: Report to The Smitsonian Institution; 1982.

12. Karpowicz A. A Study on development of cracks on paintings. J Am Inst Conserv. 1990;29(2):169-80.

13. Carlyle L, Young C, Jardine S. The mechanical response of flour-paste grounds. In: Townsend JH, Doherty T, Heydenreich G, Ridge J, editors. Preparation for painting: the artist's choice and its consequences. London: Archetype Publications Ltd.; 2008. p. 123-31.

14. Carlyle LA. The artist's assistant: oil painting manuals and handbooks in Britain 1800-1900 with reference to selected eighteenth-century sources. London: Archetype Publications; 2001

15. Bouviers MBL. Vollständige Anweisung zur Oehlmalerei für Künstler und Kunstfreunde. 2nd ed. Halle: Schwetschke und Sohn; 1838.

16. Lluveras A, Bonaduce I, Andreotti A, Colombini MP. GC/MS analytical procedure for the characterization of glycerolipids, natural waxes, terpenoid resins, proteinaceous and polysaccharide materials in the same paint microsample avoiding interferences from inorganic media. Anal Chem. 2010;82(1):376-86.

17. Bonaduce I, Cito M, Colombini MP. The development of a gas chromatographic-mass spectrometric analytical procedure for the determination of lipids, proteins and resins in the same paint microsample avoiding interferences from inorganic media. J Chromatogr A. 2009;1216(32):5931-9.
18. Lluveras-Tenorio A, Mazurek J, Restivo A, Colombini MP, Bonaduce 1. Analysis of plant gums and saccharide materials in paint samples: comparison of GC-MS analytical procedures and databases. Chem Cent J. 2012;6(1):115

19. Lluveras-Tenorio A, Mazurek J, Restivo A, Colombini MP, Bonaduce I. The development of a new analytical model for the identification of saccharide binders in paint samples. PLoS ONE. 2012;7(11):e49383.

20. Colombini MP, Andreotti A, Bonaduce I, Modugno F, Ribechini E. Analytical strategies for characterizing organic paint media using gas chromatography/mass spectrometry. Acc Chem Res. 2010;43(6):715-27.

21. Mills JS. The gas chromatographic examination of paint media. Part I. Fatty acid composition and identification of dried oil films. Stud Conserv. 1966;11(2):92-107.

22. Shilling MR, Carson DM, Khanjian HP. Evaporation of fatty acids and the formation of ghost images by framed oil paintings. Western Association for Art Conservation (WAAC) Newsletter. 1998;21(1):4.

23. Bonaduce I, Carlyle L, Colombini MP, Duce C, Ferrari C, Ribechini E, et al. New insights into the ageing of linseed oil paint binder: a qualitative and quantitative analytical study. PLoS ONE. 2012;7(11):e49333.

24. Cove S. Mixing and mingling: John Constable's oil paint mediums C 1802-37, including the analysis of the 'Manton' paint box. Stud Conserv. 1998:43(supp1):211-6.

25. Burley RW, Vadehra DV. Chemistry and biology technological nonfood uses of eggs. In: Burley RW, Vadehra DV, editors. The Avian egg. New York: Wiley; 1989. p. 365-70.

26. Gettens RJ, Stout GL. Painting materials: a short encyclopedia. Toronto and London: Dover Publications; 1966.

27. Matteini M, Mazzeo R, Moles A. Chemistry for restoration, painting and restoration materials. Florence: Nardini Editore; 2016.

28. Khandekar N, Phenix A. Some observations on the effects of pigments on an artificially aged egg tempera paint film. AlCCM Bull. 2000;25:1-7.

29. Casoli A, Berzioli M, Cremonesi P. The chemistry of egg binding medium and its interactions with organic solvents and water. In: Fuster-Lopez L, Charola AE, Mecklenburg MF, Domenech-Carbo MT, editors. New insights into the cleaning of paintings; Valencia. Washington: Universidad Politécnica de Valencia and Museum Conservation Institute; 2013. p. 39-44.

\section{Submit your manuscript to a SpringerOpen ${ }^{\circ}$ journal and benefit from:}

- Convenient online submission

- Rigorous peer review

- Open access: articles freely available online

- High visibility within the field

- Retaining the copyright to your article

Submit your next manuscript at $\boldsymbol{\nabla}$ springeropen.com 